\title{
Effect of Yeast and Bio-power on Growth and Fruiting of Flame Seedless Grapevines
}

\author{
El-Salhy, A.M. ${ }^{1}$; H.A. Abdel-Galil ${ }^{1}$; R.A. Ibrahim ${ }^{1}$; A.Y. Halim ${ }^{2}$ and \\ M.K. Sayed ${ }^{3}$ \\ ${ }^{1}$ Pomology Dept., Fac. Agric., Assiut Univ., Assiut, Egypt. \\ ${ }^{2}$ Desert Research Center, El-Matariya, Cairo, Egypt. \\ ${ }^{3}$ Hort. Dept., Fac. Agric., New Valley, Assiut Univ.
}

Received on: 16/11/2016

Accepted for publication on: 19/12/2016

\begin{abstract}
This investigation was carried out during 2015 \& 2016 seasons, at Afak farm located at Balat district, New Valley Governorate. To study the effect of yeast and bio-power vegetative growth, nutrient status, and fruiting of Flame Seedless grapevines. The experiment was arranged in a complete randomized block design with seven treatments and three replications consisting of two vines per each.
\end{abstract}

The obtained results could be summarized as follow:

Using the recommended dose of nitrogen (RDN) via $25 \%$ mineral plus $75 \%$ bio-form significantly increased the number of leaves/shoot and leaf area as well as leaf nutrient composition compared to use $\mathrm{RDN}$ via mineral $\mathrm{N}$ fertilizer alone. No significant differences on these traits due to use RDN via bio-form plus either 75 or $50 \%$ mineral-N. Also, no significant differences on shoot length due to use the double or triple form of fertilization compared to use mineral-N only. All combined fertilization treatments significantly increased the yield and improved the cluster and berry traits compared to use RDN via mineral source only.

It is evident from the foregoing results that double form $(50 \%$ plus $50 \%$ yeast or bio-power) or triple form of fertilization $(25 \% \mathrm{~m}+25$ or $50 \%$ yeast plus 50 or $25 \%$ bio-power) improved the vegetative growth, yield and berry quality. In addition, it minimized the production costs and environmental pollution.

Keywords: Bio-fertilizers, yield, berry quality, environmental pollution.

\section{Introduction}

Grape (Vitis vinifera, L.) is considered as one of the most popular and favorite fruit crops in the world, for being of an excellent flavor, nice taste and high nutritional value. In Egypt, it ranked the second fruit crop after citrus. Due to its high net return, the cultivated area has grown rapidly, especially in the reclaimed lands. It reached about 192934 feddans, the fruitful ones are about 171882 feddans with a total annual production of 1596169 tons according to the statis- tics of M.A.L.R. (2014). The grapevines require adequate cultural practices, appropriate climatic and soil conditions. Fertilization is one of the most important management to improve the soil fertility and increase crop yield. Nitrogen has a pronounced role to improve production and fruit quality. This fact is fluctuated according to the side of the area, amount applied, the dose as well as the sources and time applied.

Nitrogen has many functions in plant life being part of proteins, an 
important constituent of protoplasm, responsible for biosynthesis of enzymes, amino acids, plant pigments and encouragement of cell division (Nijjar, 1985 and Mengel and Kirkby, 2001). The relationship between yield, fruit quality and health seems to be a complex and can be influenced by nitrogen fertilization (ElSalhy et al., 2013). Continuous use of chemical fertilization leads to the deterioration of soil characteristics and fertility and might lead to the accumulation of metals in plant tissues, affecting the fruit nutritional value and edibility. They not only have harmful effects on the environment but also they are a very great danger that harmful residues may remain in food (Bogatyre, 2000; Shimbo et al., 2001 and Keller, 2005).

Controlling chemical fertilization, especially $\mathrm{N}$ fertilizer is very important for reducing environmental pollution and obtaining safe produce. Using bio-fertilizers relatively a good method in this respect (El-Haddad et al., 1993; Verma, 1999; Ram Rao et al., 2007 and El-Salhy et al., 2011).

Application of bio-fertilizers containing beneficial microorganisms instead of synthetic chemicals are known to improve plant growth through the supply of plant nutrients and may help to sustain environmental health and soil productivity. They are known to improve fixation of nutrients in the rhizosphere, produce growth stimulants for plants, improve soil stability, provide biological control, biodegrade substance, recycle nutrients, promote mycorrhiza symbiosis and develop bioremediation process in soil contaminated with toxic, xenobi- otic and recalcitrant substances. Additionally, the use of bio-fertilizers can improve productivity per unit area in a relatively short time, consume smaller amounts of energy, mitigate contamination of soil and water, increase soil fertility, and promote autogonism and biological control of phytopathogenic organisms (Shimbo et al., 2001; Abdel-Hamid, 2002; Chirinos et al., 2006 and ElSalhy et al., 2006). Supplying the various grapevine cultivar with biofertilizers only or beside mineral-N source caused a pronounced increase in vegetative growth and nutritional status of vines, as well as in yield components, cluster traits and berry quality (Abdel-Hady, 2003; ElShenawy and Fayd, 2005; Abbas et al., 2006; Mostafa, 2008; AbdelMonem et al., 2008;El-Sabagh et al, 2011 and El-Salhy et al., 2011 and Masoud, 2012).

The yeast is considered as one of promising bio-fertilizer for many crops. Yeast contains a large amount of minerals, proteins, vitamin $\mathrm{B}$ and cytokinins. It is very effective for releasing $\mathrm{CO}_{2}$ which improves net photosynthesis (Idso et al., 1995).

Bio-stimulants are biologically active substances, which may contain e.g. hormones proteins and microelements and their role is to improve plant growth and development (Jankowski and Dubis, 2008). Biofertilizers may help in improving crop productivity and quality by increasing the biological $\mathrm{N}$ fixation, the availability and uptake of nutrients, and stimulating the natural hormones (Kannaiyan, 2002).

In this respect, many researchers emphasized the importance of the 
aforementioned practices to increase the growth and fruiting of grapevines (El-Mogy et al., 1998; Esmaeil et al., 2003; Gaser et al., 2006; El-Salhy et al., 2006; Abdel-Monem, 2008; Hegab et al., 2010; El-Sabagh et al., 2011; El-Salhy et al., 2011 and ElSalhy et al., 2013).

Therefore, the objective of this investigation was to study the possibility of using bio-fertilization partially instead of completed mineral fertilizers on growth and fruiting of Flame Seedless grapevines.

\section{Materials and Methods}

The present study was executed in 2015 and 2016 seasons on Flame Seedless grapevines grown in Afak farm situated at Blat district, New Valley Governorate, Egypt. Soil of the vineyard is silty clay and its some physical and chemical properties were determined according to Wilde et al. (1985) and are present in Table (1). The vines were 6 years old at the starting of this experiment and spaced at $1.5 \times 3$ meters apart. The vines trained according to the double cordon system and supported with Gable shape. Pruning was carried out at the second week of December by leaving 14 fruiting spurs with 3 buds each spur plus four replacement spurs with 2 buds each. Forty-two healthy vines, with no visual nutrient deficiency symptoms and at almost uniform in their vigor were chosen and divided into seven different treatments including the control. The treatments were as follows:

1- The application of $75 \%$ mineral nitrogen plus $25 \%$ yeast, as bioform.

2- The application of $75 \%$ mineral nitrogen plus $25 \%$ bio-power

3- The application of $50 \%$ mineral nitrogen plus $50 \%$ yeast.

4- The application of $50 \%$ mineral nitrogen plus $50 \%$ bio-power.

5- The application of $25 \%$ mineral nitrogen plus $50 \%$ yeast plus $25 \%$ bio-power.

6- The application of $25 \%$ mineral nitrogen plus 50\% bio-power plus $25 \%$ yeast.

7- The application of $100 \%$ mineral nitrogen (control).

Table 1. Some physical and chemical properties of the experiment soil.

\begin{tabular}{|l|c|l|c|}
\hline \multicolumn{1}{|c|}{ Soil properties } & Values & \multicolumn{1}{|c|}{ Soil properties } & Values \\
\hline Sand \% & 20.0 & Total nitrogen & 0.19 \\
\hline Silt \% & 26.0 & Available-P $(\mathrm{ppm})$ & 5.18 \\
\hline Clay \% & 54.0 & E-c $(1: 2.5$ extract $) \mathrm{m}$ mmhas & 2.3 \\
\hline Texture grade & Silty clay & $\mathrm{K} \mathrm{mg} / 100 \mathrm{~g}$ & 6.6 \\
\hline $\mathrm{PH}(1: 2.5)$ & 7.76 & Fe $(\mathrm{ppm})$ DTPA Extractable & 7.50 \\
\hline $\mathrm{CaCO}_{\mathbf{3}} \%$ & 1.9 & $\mathrm{Mn}(\mathrm{ppm})$ DTPA Extractable & 5.20 \\
\hline Organic matter \% & 1.22 & Zn $(\mathrm{ppm})$ DTPA Extractable & 1.80 \\
\hline
\end{tabular}

Each treatment had under the recommended $\mathrm{N}$ level $(80 \mathrm{~g}$ $\mathrm{N} /$ vine/year). Urea $(46.5 \% \mathrm{~N})$ as a mineral source was applied at three times: growth start, immediately after berry set and at two months later. The active dry yeast and bio-power as a bio-fertilizer $(0.5$ to $1.0 \%)$ were sprayed twice at growth start and at two month later. The pure dry yeast powder was activated by using sources of carbon and nitrogen with ratio 6:1. This ratio is suitable to get the highest vegetative production of yeast each $\mathrm{ml}$ of activated contained about 12000 yeast cells (Barnett et 
al., 1990). Bio-power as biostimulants that contain amino acids (proteins), nutrients (macro \& microelements), vitamin and hormones. Solution of yeast and bio-power concentrations were prepared with distilled water and then sprayed. Normal agricultural and horticultural practices used in vineyard (except fertilization) were carried out. The experiment was arranged in a complete randomized block design with three replications consisting of two vines per each.

The following parameters were determined to evaluate the effects of different fertilization treatments on growth, nutrient status, yield and berry quality.

1- Some vegetative growth Parameters:

All vegetative growth traits i.e. main shoot length $(\mathrm{cm})$, number of leves/shoot and leaf area were measured in the middle of July.

The average leaf area $\left(\mathrm{cm}^{2}\right)$ : Twenty leaves from those opposite to basal clusters were measured according to the following equation that was reported by Ahmed and Morsy (1999) leaf area $=0.56(0.79 \times \mathrm{w} 2)+20.01$, where, $\mathrm{w}=$ the maximum leaf width.

\section{2- Leaf nutritional status:}

Samples of 30 leaves for each replication were collected from the first full mature leaves from the top of shoots in mid of July and leaf petioles were separated from the blades. The petioles were washed with tap water, distilled water, air-dried, ovendried at $70^{\circ} \mathrm{C}$ to constant weight, then ground in a stainless steel mill. Wet digestion was done by using concentrated sulphoric acid and hydrogen peroxide for overnight. Percentages of $\mathrm{N}, \mathrm{P}$ and $\mathrm{K}$ (on dry weight basis) were determined in the digestion according Wilde et al. (1985).

\section{3- Yield:}

At harvest date, the yield per vine was recorded in terms of weight $(\mathrm{kg})$ and number of clusters per vine. 4- Cluster and berry characteristic:

At harvest time, two clusters were randomly taken from the yield of each vine to determine the cluster and berry traits such as cluster weight and cluster compactness coefficient. Berry quality such as berry weight, reducing sugar percentages, total soluble solids and total acidity (expressed as gm tartaric acid per $100 \mathrm{ml}$ juice), berry properties were evaluated according to A.O.A.C. methods (1985). In addition, the anthocyanin content was determined according to Markham (1982). All the obtained data were tabulated and analyzed according to Gomez and Gomez, (1984) using L.S.D. test for distinguishing the significance differences between various treatment means according to Steel and Torrie (1980).

\section{Results}

1- Vegetative growth and leaf nutritional status:

Data presented in Tables $(2 \&$ 3 ) showed the effect of yeast or biostimulants as a bio-fertilization on shoot length and number of leaves/shoot and leaf area as well as leaf N, P \& K\% of Flame Seedless grapevines during 2015 and 2016 seasons. It is obvious from the data that the results took similar trend during the two studied seasons.

In a general view, data in prementioned tables showed that the application of the required $\mathrm{N}$ through using 75 or $50 \%$ of the recommended dose of nitrogen (RDN) as mineral $\mathrm{N}$ 
along with using 25 or $50 \%$ as yeast or bio-power form significantly increased such traits excepted shoot length compared to using RDN only as a mineral $\mathrm{N}$ fertilizer. The promotion on such growth traits was associated with increasing the applied level of the bioform from 25 to $50 \%$. Moreover, applications of the suitable amount of $\mathrm{N}$ via $25 \%$ as a mineral $\mathrm{N}$ plus $75 \%$ bio-form significantly stimulated the leaves number/shoot and leaf area as well as $\mathrm{N}, \mathrm{P}$ and $\mathrm{K}$ contents of leaves more than $75 \%$ mineral $\mathrm{N}$ plus $25 \%$ bio-form. The maximum values of shoot length and leaf traits were recorded on the vines that were fertilized with the required $\mathrm{N}$ as $25 \%$ in a mineral $\mathrm{N}$ along $25 \%$ yeast plus $50 \%$ bio-power. On other hand, the lowest values of the growth traits as well as N, P and $\mathrm{K}$ contents were recorded for the vines that were treated with $100 \%$ mineral $\mathrm{N}$ (check trees). The highest leaf area was $\left(169.4 \& 177.5 \mathrm{~cm}^{2}\right)$ and $(171.5 \&$ $179.6 \mathrm{~cm}^{2}$ ) due to use $25 \%$ mineral plus $50 \%$ yeast along $25 \%$ bio-power $\left(\mathrm{T}_{5}\right)$ and $25 \%$ mineral plus $25 \%$ yeast along 50\% bio-power $\left(\mathrm{T}_{6}\right)$ during the two studied seasons, respectively. On other hand, the lowest ones due to use $100 \%$ mineral-N (control, $\mathrm{T}_{7}$ ) was $\left(154.6 \& 163.5 \mathrm{~cm}^{2}\right)$ during the two studied seasons, respectively. Then, the increment percentage of the leaf area was $(9.57 \& 8.56 \%)$ and $(10.93$ $\& 9.85 \%)$ due to $\mathrm{T}_{5}$ and $\mathrm{T}_{6}$ compared to the check treatment $\left(\mathrm{T}_{7}\right)$, respectively. Also, the highest N\% were $(1.45 \& 1.53 \%)$ and $(1.47 \& 1.55 \%)$ due to $\mathrm{T}_{5}$ and $\mathrm{T}_{6}$ against lowest ones (1.34 \& $1.41 \%)$ due to 100 mineral-N (control). Hence, the increment percentage of $\mathrm{N} \%$ due to $\mathrm{T}_{5}$ and $\mathrm{T}_{6}$ over control attained $(8.21 \& 8.51 \%)$ and (9.70 \& 9.92\%). Therefore, $\mathrm{N}$ fertilization with bio-sources as a partial substitute for mineral ones significantly increased the total leaf surface area, nutritional status and vegetative growth of vines as well as decreased the opportunity of the environmental pollution.

\section{2- Yield and cluster characteristics:}

Data presented in Table (4) showed that the number of clusters per vine on 2015 season did not alter with varying the fertilization treatments. On the other studied season, using nitrogen fertilization as double form (mineral-plus bio) or triple form (mineral + yeast and bio-power) significantly increased the cluster numbers/vine compared to application of $\mathrm{N}$ as $100 \%$ via mineral fertilization. Using whatever yeast or bio-power plus mineral-N significantly caused a remarkable promotion on cluster weight and yield/vine compared to using RDN via mineral source only. On other hand, no significant effects on compactness coefficient as influenced by using combined fertilization. Moreover, fertilized by combined at the three forms gave the highest values of these traits and least values of compactness coefficient comparing with other fertilization treatment. The obtained highest of cluster weight values were (350.4 \& $383.2 \mathrm{~g})$ and (357.8 \& $390.6 \mathrm{~g})$ and yield/vine $(9.85 \& 12.72 \mathrm{~kg})$ and (10.13 \& $13.40 \mathrm{~kg} / \mathrm{vine})$ due to fertilize by $25 \% \mathrm{~m}$ plus $50 \%$ yeast and $25 \%$ bio-power, $\mathrm{T}_{5}$ or $25 \% \mathrm{~m}$ plus $25 \%$ yeast and $50 \%$ bio-power, $\mathrm{T}_{6}$ during the two studied seasons, respectively. Contrarly, these values on check vines were $(289.8$ \& $315.6 \mathrm{~g})$ 
and $(7.97 \& 9.06 \mathrm{~kg} / \mathrm{vine})$, respectively. Hence the corresponding increment percentages for these traits over check treatment were $(20.91 \&$ $21.42 \%)$ and (23.46 \& $23.76 \%)$ as well as (23.59 \& 27.10\%) and (40.49 \& 47.90\%), respectively.

In general, it could be concluded that combined the biofertilization with mineral-N fertilization had increasing effects on productivity of Flame seedless grapevines.

\section{3- Berry quality:}

It can be concluded from data in Table (5) that bio-fertilization in combination with mineral-N significantly increased the berry weight compared to use mineral only. The heaviest 25 berry weight recorded on vines that received the RDN via three forms, $\mathrm{T}_{5}(55.1 \& 57.8 \mathrm{~g})$ and $\mathrm{T}_{6}$ $(56.0$ \& $58.2 \mathrm{~g})$, respectively, whereas, the lightest 25 berry weight was found on vines that fertilized by $100 \%$ mineral-N (50.6 \& $53.3 \mathrm{~g}$ ), respectively. Hence the increment percentage of berry weight due such treatments over check treatments $\mathrm{T}_{7}$ was $(8.89 \& 8.44 \%)$ and $(10.67 \&$ $9.19 \%)$, respectively.

Table 2. Effect of bio-fertilization on some vegetative growth aspects of Flame Seedless grapevines during 2015 and 2016 seasons.

\begin{tabular}{|c|c|c|c|c|c|c|}
\hline \multirow[t]{2}{*}{ Treatments } & \multicolumn{2}{|c|}{$\begin{array}{l}\text { Shoot length } \\
\text { (cm) }\end{array}$} & \multicolumn{2}{|c|}{$\begin{array}{c}\text { No. } \\
\text { leaves/shoots }\end{array}$} & \multicolumn{2}{|c|}{ Leaf area $\mathrm{cm}^{2}$} \\
\hline & 2015 & 2016 & 2015 & 2016 & 2015 & 2016 \\
\hline $1-75 \% \mathrm{Mn}+25 \%$ bio. $\mathrm{Y}\left(\mathrm{T}_{1}\right)$ & 86.9 & 93.2 & 21.2 & 21.9 & 161.4 & 170.1 \\
\hline $2-75 \% \mathrm{Mn}+25 \%$ bio. $\mathrm{B}\left(\mathrm{T}_{2}\right)$ & 86.8 & 92.6 & 21.3 & 22.1 & 163.2 & 172.5 \\
\hline 3- $50 \% \mathrm{Mn}+50 \%$ bio. $\mathrm{Y}\left(\mathrm{T}_{3}\right)$ & 85.0 & 90.8 & 21.5 & 22.6 & 164.3 & 172.8 \\
\hline $4-50 \% \mathrm{Mn}+50 \%$ bio. $\mathrm{B}\left(\mathrm{T}_{4}\right)$ & 84.7 & 93.4 & 21.8 & 22.5 & 167.6 & 173.0 \\
\hline $5-25 \% \mathrm{Mn}+50 \%$ bio. $\mathrm{Y}+25 \%$ bio. $\mathrm{B}\left(\mathrm{T}_{5}\right)$ & 84.8 & 92.1 & 22.1 & 23.2 & 169.4 & 177.5 \\
\hline $6-25 \% \mathrm{Mn}+25 \%$ bio. $\mathrm{Y}+50 \%$ bio. $\mathrm{B}\left(\mathrm{T}_{6}\right)$ & 86.2 & 91.3 & 22.4 & 23.3 & 171.5 & 179.6 \\
\hline 7- $100 \% \mathrm{Mn}$ (control) $\left(\mathrm{T}_{7}\right)$ & 85.8 & 91.4 & 20.6 & 21.4 & 154.6 & 163.5 \\
\hline LSD 5\% & N.S. & N.S. & 0.7 & 0.9 & 6.41 & 9.73 \\
\hline
\end{tabular}

Table 3. Effect of bio-fertilization on percentage of $N, P \& K$ in leaves of Flame Seedless grapevines during 2015 and 2016 seasons.

\begin{tabular}{|l|c|c|c|c|c|c|}
\hline \multirow{2}{*}{ Treatments } & \multicolumn{2}{|c|}{ N \% } & \multicolumn{2}{c|}{ P \% } & \multicolumn{2}{c|}{ K \% } \\
\cline { 2 - 7 } & $\mathbf{2 0 1 5}$ & $\mathbf{2 0 1 6}$ & $\mathbf{2 0 1 5}$ & $\mathbf{2 0 1 6}$ & $\mathbf{2 0 1 5}$ & $\mathbf{2 0 1 6}$ \\
\hline $\mathrm{T}_{\mathbf{1}}$ & 1.42 & 1.50 & 0.263 & 0.298 & 0.81 & 0.89 \\
\hline $\mathrm{T}_{\mathbf{2}}$ & 1.43 & 1.49 & 0.245 & 0.276 & 0.86 & 0.93 \\
\hline $\mathrm{T}_{\mathbf{3}}$ & 1.43 & 1.51 & 0.274 & 0.312 & 0.91 & 1.06 \\
\hline $\mathrm{T}_{\mathbf{4}}$ & 1.45 & 1.53 & 0.260 & 0.303 & 0.80 & 0.88 \\
\hline $\mathrm{T}_{\mathbf{5}}$ & 1.45 & 1.53 & 0.280 & 0.321 & 0.92 & 1.10 \\
\hline $\mathrm{T}_{\mathbf{6}}$ & 1.47 & 1.55 & 0.268 & 0.295 & 0.94 & 1.10 \\
\hline $\mathrm{T}_{\mathbf{7}}$ & 1.34 & 1.41 & 0.212 & 0.241 & 0.73 & 0.76 \\
\hline LSD 5\% & $\mathbf{0 . 0 5}$ & $\mathbf{0 . 0 6}$ & $\mathbf{0 . 0 1 6}$ & $\mathbf{0 . 0 1 9}$ & $\mathbf{0 . 0 6}$ & $\mathbf{0 . 0 8}$ \\
\hline
\end{tabular}


Table 4. Effect of bio-fertilization on yield and some cluster traits of Flame Seedless grapevines during 2015 and 2016 seasons.

\begin{tabular}{|l|c|c|c|c|c|c|c|c|}
\hline \multirow{2}{*}{ Treatments } & \multicolumn{2}{|c|}{$\begin{array}{c}\text { Cluster weight } \\
\text { (g) }\end{array}$} & \multicolumn{2}{c|}{$\begin{array}{c}\text { Clusters } \\
\text { number }\end{array}$} & \multicolumn{2}{c|}{$\begin{array}{c}\text { Yield/vine } \\
\text { (kg) }\end{array}$} & \multicolumn{2}{c|}{$\begin{array}{c}\text { Compactness } \\
\text { coefficient }\end{array}$} \\
\cline { 2 - 9 } & $\mathbf{2 0 1 5}$ & $\mathbf{2 0 1 6}$ & $\mathbf{2 0 1 5}$ & $\mathbf{2 0 1 6}$ & $\mathbf{2 0 1 5}$ & $\mathbf{2 0 1 6}$ & $\mathbf{2 0 1 5}$ & $\mathbf{2 0 1 6}$ \\
\hline $\mathrm{T}_{\mathbf{1}}$ & 335.8 & 364.6 & 27.6 & 31.8 & 9.27 & 11.58 & 6.65 & 6.60 \\
\hline $\mathrm{T}_{\mathbf{2}}$ & 338.7 & 366.5 & 27.1 & 30.9 & 9.18 & 11.32 & 6.51 & 6.52 \\
\hline $\mathrm{T}_{\mathbf{3}}$ & 340.1 & 360.5 & 27.8 & 33.7 & 9.45 & 12.15 & 6.43 & 6.29 \\
\hline $\mathrm{T}_{\mathbf{4}}$ & 344.1 & 373.6 & 28.3 & 33.3 & 9.74 & 12.44 & 6.40 & 6.60 \\
\hline $\mathrm{T}_{\mathbf{5}}$ & 350.4 & 383.2 & 28.1 & 33.2 & 9.85 & 12.72 & 6.23 & 6.12 \\
\hline $\mathrm{T}_{\mathbf{6}}$ & 357.8 & 390.6 & 28.3 & 34.3 & 10.13 & 13.40 & 6.11 & 6.18 \\
\hline $\mathrm{T}_{\mathbf{7}}$ & 289.8 & 315.6 & 27.5 & 28.7 & 7.97 & 9.06 & 6.41 & 6.36 \\
\hline LSD 5\% & $\mathbf{2 3 . 1 0}$ & $\mathbf{1 8 . 7 5}$ & N.S. & $\mathbf{0 . 7 6}$ & $\mathbf{0 . 6 5}$ & $\mathbf{0 . 8 8}$ & N.S. & N.S. \\
\hline
\end{tabular}

Table 5. Effect of bio-fertilization on berry weight and chemical properties of berry of Flame Seedless grapes during 2015 and 2016 seasons.

\begin{tabular}{|l|c|c|c|c|c|c|c|c|c|c|}
\hline \multirow{2}{*}{ Treatments } & \multicolumn{2}{|c|}{$\begin{array}{c}\text { 25 berry } \\
\text { weight (g) }\end{array}$} & \multicolumn{2}{|c|}{ TSS \% } & \multicolumn{2}{c|}{$\begin{array}{c}\text { Reducing } \\
\text { sugar \% }\end{array}$} & \multicolumn{2}{c|}{$\begin{array}{c}\text { Anthocyanin } \\
\text { (mg/g) }\end{array}$} & \multicolumn{2}{c|}{ Acidity \% } \\
\cline { 2 - 12 } & $\mathbf{2 0 1 5}$ & $\mathbf{2 0 1 6}$ & $\mathbf{2 0 1 5}$ & $\mathbf{2 0 1 6}$ & $\mathbf{2 0 1 5}$ & $\mathbf{2 0 1 6}$ & $\mathbf{2 0 1 5}$ & $\mathbf{2 0 1 6}$ & $\mathbf{2 0 1 5}$ & $\mathbf{2 0 1 6}$ \\
\hline $\mathrm{T}_{\mathbf{1}}$ & 53.8 & 56.6 & 17.40 & 18.25 & 12.62 & 13.28 & 1.93 & 2.01 & 0.593 & 0.555 \\
\hline $\mathrm{T}_{\mathbf{2}}$ & 54.1 & 56.4 & 17.50 & 18.40 & 12.90 & 13.32 & 1.93 & 2.02 & 0.585 & 0.550 \\
\hline $\mathrm{T}_{\mathbf{3}}$ & 53.8 & 56.9 & 17.70 & 18.50 & 12.82 & 13.55 & 1.97 & 2.08 & 0.580 & 0.545 \\
\hline $\mathrm{T}_{\mathbf{4}}$ & 54.7 & 58.1 & 18.10 & 18.60 & 13.25 & 13.47 & 1.99 & 2.07 & 0.572 & 0.538 \\
\hline $\mathrm{T}_{\mathbf{5}}$ & 55.1 & 57.8 & 18.65 & 19.25 & 13.60 & 13.91 & 2.05 & 2.13 & 0.561 & 0.527 \\
\hline $\mathrm{T}_{\mathbf{6}}$ & 56.0 & 58.2 & 18.90 & 19.60 & 13.60 & 13.82 & 2.07 & 2.16 & 0.550 & 0.520 \\
\hline $\mathrm{T}_{\mathbf{7}}$ & 50.6 & 53.3 & 16.53 & 17.32 & 11.93 & 12.42 & 1.83 & 1.91 & 0.632 & 0.606 \\
\hline LSD 5\% & $\mathbf{2 . 1 1}$ & $\mathbf{2 . 8 1}$ & $\mathbf{0 . 6 7}$ & $\mathbf{0 . 7 2}$ & $\mathbf{0 . 6 2}$ & $\mathbf{0 . 7 8}$ & $\mathbf{0 . 0 7}$ & $\mathbf{0 . 0 8}$ & $\mathbf{0 . 0 2 8}$ & $\mathbf{0 . 0 3 5}$ \\
\hline
\end{tabular}

The increase in berry weight and size is an important target as grapes quality due to the increase in berry weight and size result in an increase in pack able yield. Also, all fertilization applications significantly improved the chemical constituents of berry juice in term of increased the total soluble solids, reducing sugars and anthocyanin contents and decreased the total acidity compared to use mineral-N only. Furthermore, vines fertilized via three forms $\left(\mathrm{T}_{5} \&\right.$ $\mathrm{T}_{6}$ ) recorded the maximum values of these traits compared to other fertilization treatments. The highest total soluble solids, reducing sugars and anthocyanin contents obtained on vines fertilized with $\left(\mathrm{T}_{\mathbf{6}}\right)$ fertilization, TSS (18.90 \& 19.60\%), anthocyanin $(2.07 \& 2.16 \mathrm{mg} / \mathrm{g})$ during the two studied seasons, respectively. Contrary, the least values of these traits were recorded on vines that fertilization by control $\left(\mathrm{T}_{7}\right) \quad(16.53 \quad \&$ $17.32 \%)$ and $(1.83 \& 1.91 \mathrm{mg} / \mathrm{g})$, respectively. Hence, the increment percentage of these attributes due to using fertilization via the three forms $\left(\mathrm{T}_{6}\right)$ over the check treatment, $\left(\mathrm{T}_{7}\right)$ attained (14.34 \& 13.66\%) and (13.11 \& 13.08\%), respectively. Also, such amending induce decrement percentage in total acidity attained (12.97 \& $14.19 \%$ ), respectively. 
On the account of the present results it could be concluded that replacing $75 \%$ of nitrogen requirements of vine by bio-form improved the growth and nutritional status as well as, yield, cluster attributes and berry quality of grapevines.

\section{Discussion:}

The role of bio-fertilization on facilitating the fixation of atmospheric $\mathrm{N}$ as well as activating the availability uptake and translocation of most nutrients, that accelerating carbohydrate and protein synthesis and movement which aid to encouraging cell division and the development of meristematic tissues. Moreover, it enhancing the resistance of plants to root diseases and controlling vegetative growth of trees, then, improving its productivity (Gaur et al., 1980 and Suba Rao, 1984). In addition, the yeast and bio-power have high content of nutrients, amino acids, vitamins and cytokinins. The effect of bio-fertilizer on activating the synthesis of total carbohydrates and proteins which enhances cell division and enlargement leading to improving the vine growth and nutritional status and maintaining a good balance between total carbohydrates and nitrogen in favor improving bud burst and fertility coefficient that lead to an increase of cluster number per vine, hence the yield was increased and hastened the maturation and improved berry quality. These results agree with those of Abdel-Hamid (2002), Abdel-Hady (2003), ElShenawy and Fayed (2005), Abbas et al. (2006), El-Salhy et al. (2006), Mostafa (2008), Abdel-Monem et al. (2008), Hegab et al. (2010), ElSabagh et al. (2011), El-Salhy et al.
(2011), Masoud (2012) and El-Salhy et al. (2013). concluded that application $\mathrm{N}$ via mineral and bio form was improved the growth aspects, yield and berry quality.

\section{Conclusion:}

So it could be concluded that replacing $50-75 \%$ of nitrogen requirements for grapevines by either organic manure or bio-fertilization, are sufficient to improve nutritional status of grapevines and gave a suitable yield with high cluster and berry traits. In addition minimized the production cost and the environmental Pollution which could be occurred by excess of chemical fertilizers.

\section{References}

A.O.A.C. 1985. Association of Official Agricultural Chemists, Official Methods of Analysis A.O.A.C. Benjamin Franklin Station, Washington, D.C.M.S.A. pp: 440-512.

Abbas, E.S.; S.A. Bondok and M.H. Rizk. 2006. Effect of bio and nitrogen mineral fertilizers on growth and berry quality of Ruby seedless grapevines. J.Agric. Sci. Mansoura, 31(7): 4565-4577.

Abdel-Hady, A.M. 2003. Response of Flame seedless vines to application of some bio-fertilizers. Minia J. Agric. Res. \& Develop, 23(4): 667-680.

Abdel-Hamid, S.Y. 2002. Effect of biofertilizer on yield and berry quality of grapevines. M.Sc. thesis, Fac. Agric., Mansoura Univ., Egypt.

Abdel-Monem, E.A.A.; M.A.S. Saleh and E.A.M. Mostafa. 2008. Minimizing the quantity of mineral nitrogen fertilizers on grapevine by using humic acid, organic and biofertilizers. Res. of Agric. and Biol. Sci., 4 (1): 46-50.

Ahmed, A.M.; H.A. El-Sayed and M.M. Shoeib. 2003. Effect of bio and organic source of $\mathrm{N}$ as a partial sub- 
stitute for chemical fertilizer on bud behavior growth and fruiting of Flame seedless grapevines. Minia. Agric. Res., Develop., 23: 259-246.

Ahmed, F.F. and M.H. Morsy. 1999. A new method for measuring leaf area in different fruit crops. Minia J. of Agric. Res. \& Develop., 19: 97-105.

Annual Reports of Statistics Institute and Agricultural Economic Dept., Ministry of Agric., Egypt, 2014.

Barnett, J.A.; R.W. Payne and D. Yarrow. 1990. Yeast, characteristics and identification. Cambridge University Press, London, 999 pp.

Bogatyre, A.N. 2000. What are we do to eat or how to live longer? Pishchevaya Promyshlemost, 7: 34-35. (C.f.CAB).

Chrinos, J.; A. Leal and J. Montilla. 2006. Use alternative biological inputs for sustainable agriculture in the south of Anzaatequi state. Applied and Inter disciplinary Science, Biotechnology. Digital Magazine Ceniap Today, 11: 1-7.

El-Haddad, M.E.; Y.Z. Ishac and M.L. Mostafa. 1993. The role of biofertilizers in reducing agricultural costs, decreasing environmental pollution and raising crop yield. Arab Univ. J. of Agric. Sci. Ain Shams Univ. Cairo, 1(1): 147-195.

El-Mogy, M.M.; A.H. Omar and S.A. Gaser, Aisha. 1998. Effect of yeast application on bud fertility physical, chemical properties, vegetative growth and yield of Thompson seedless grapevine. J. Agric. Sci. Mansoura Univ., 28 (8): 38793886.

El-Sabagh, A.S.; F.M. El-Morsy and A.R. Farag. 2011. Effect of biofertilizers as a partial substitute for nitrogen on vegetative growth, yield, fruit quality and leaf mineral content of two seedless grape cul- tivars. 1- Vegetative growth and yield. J. of Horti. Sci. \& Ornam. Plants, 3 (2): 166-175.

El-Salhy, A.M.; H.M. Mazrouk and M.M. El-Akkad. 2006. Biofertilization and elemental sulphur effects on growth and fruiting of King's Ruby and Roomy grapevines. Egyptian J. of Horti., 33: 2944.

El-Salhy, A.M.; K.I.A. Amen; A.A.B. Masoud and A.A. Eman Abozed. 2011. Response of Ruby seedless and Red Roomy grapevines to application of some bio-fertilizers. Assiut J. Agric. Sci., 41 (5): 125 142.

El-Salhy, A.M.; Kamelia, A. Amin; E.A. Hassan and Shimaa H. Gaber. 2013. The effect of different sources of nitrogen and potassium fertilization on growth and fruiting of Thompson seedless grapevines. 1stAssiut St. Assiut Inter. Conf. Hort., pp. 116-132.

El-Shenawy, F.E. and T.A. Fayed. 2005. Evaluation of the convential to organic and bio-fertilizers on Cirmson seedless grapevine in comparison with chemical fertilization. 2Yield and fruit quality. Egypt. J. Appl. Sci., 20 (1): 212-225.

Esmaeil, F.H.; M.T. Wahdan and A.F. El-Sheikh. 2003. Response of Thompson Seedless and Roumi Red grape cultivars to foliar sprays with yeast extract and $\mathrm{GA}_{3} . \mathrm{J} . \mathrm{Ag}$ ric. Sci., Mansoura Univ., 28 (8): 6321-6334.

Gaser, Aisha, S.A.; A. El-Helw, Hanna and M.A. Abd El-Wahab. 2006. Effect of yeast doses and time of application on growth, yield and fruit quality of Flame seedless grapevines. Egypt. J. of Appl. Sci., 21 (8B): 661-681.

Gaur, A.C.; K.P. Ostwal and R.S. Mathur 1980. Save superphosphate 
by using phosphor- bacteria. Kheti, 32: 23-35.

Gomez, K.A. and A.A. Gomez. 1984. Statistical Procedures for Agricultural Research, $2^{\text {nd }}$ Ed. Willy, New York.

Hegab, M.M.; M.I.F. Fawiz and N.E. Ashour. 2010. Effect of different yeast doses and time of application on growth, yield and quality of Ruby seedless grapevines. Minia J. of Agric. Res. \& Develop., 30 (1): 231-242.

Idso, S.B.; K.E. Idso; R.L. Garcia; B.A. Kimball and J.K. Hoober. 1995. Effect of atmospheric $\mathrm{CO}_{2}$ environment and foliar methanol application on net photosynthesis of sour orange trees (Citrus aurantium, L.) leaves. Amer. J. of Botany, 82 (1): 26-30.

Jankowski, K. and B. Dubis. 2008. Biostimulators in plant field production. Mat. Conf. Bio-stimulators in Modern Plant Breeding. Plant Press. Warsaw, 24-25.

Kannaiyan, S. 2002. Biotechnology of bio-fertilizers Alpha Sci. Inter Ltd. P.O. Box 4067 Pang Bourne R. 68. M.K. pp: 1-275.

Keller, M. 2005. Nitrogen-fielded for of wine quality. Practical winery and vineyard magazine 58D Paul Drive, San Rafael, CA 94903-1534 (9) issue.

M.A.L.R. 2014: Ministry of Agriculture and Land Reclamation Economic Affairs Sector Bull., Agric. Statistics.

Markham, K.P. 1982. Technique of flovonaids identification. Academic press. London.

Masoud, A.A.B. 2012. Effect of organic and bio nitrogen fertilization on growth, nutrient status and fruiting of Flame seedless and Ruby seedless grapevines. J. of Agric. and Biolo. Sci., 8 (2): 83-91.
Mengel, K. and E.A. Kirkby. 2001. Principles of Plant Nutritioin. 5th rev. ed, Kluwer Academic Publishers (United States), ISBN10: 1402000081.

Mostafa, R.A.A. 2008. Effect of bio and organic nitrogen fertilization and elemental sulpher application on growth, yield and fruit quality of Flame seedless grapevines Assiut J. Agric. Sci., 39(1): 79-96.

Nijjar, G.S. 1985. Nutrition of Fruit Trees. Mrs. Usha Raji Kumar, Kilyani, New Delhia, India, 206234.

Ram Rao, D.M.; J. Kodandaramaiah; M.P. Reddy; R.S. Katiyar and V.K. Rahmathulla. 2007. Effect of AM fungi and bacterial biofertilizers on mulberry lef quality and silkworm cocoon characters under semiarid conditions. Caspian J. Env. Sci., 5 (2): 111-117.

Shimbio, S.; Z.W. Zhang; T. Watanable; H. Nakatsuka; N. MatsudaInoguch; K. Higashikawa and M. Ikeda. 2001. Cadmium and lead contents in rice and other cereal products in Japan in 1998-2000. Sci. of Total Environ. 281: 165174.

Steel, R.G.D. and J.H. Torrie 1980. Principles and procedures of statistics: Biometrical approach Mc-Grow Hill Book company (2nd Ed) N.Y, pp: 631.

Suba Rao, N.S. 1984. Bio-fertilizers in Agriculture Oxford. IBH Company. New Delhi.

Verna, L.N. 1999. Role of biotechnology in supplying plant nutrients in the vineties. Fertilizer news., 35: 8797.

Wilde, S.A.; R.B. Corey; J.G. Lyer and G.K. Voigt. 1985. Soil and plant analysis for tree cultivars. Oxford, IBH, New Delhi, India, pp: 94105. 
تأثثير رش الخميرة والمنشط الحيوي علي نمو وإثمار كروم العنب الفليم عديم البذور

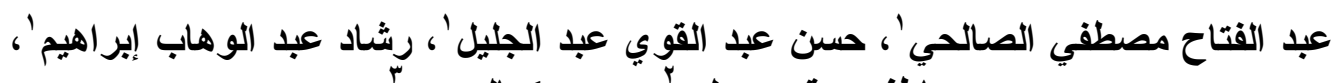

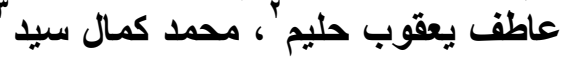

$$
\begin{aligned}
& \text { ' قسم الفاكهة - كلية الزر اعة - جامعة أسيوط لماط } \\
& \text { r مركز بحوث الصحر اء - المطرية - القاهرة - مصر } \\
& \text { × قسم البساتين - كلية الزر اعة بالو ادي الجديد - جامعة أسيوط }
\end{aligned}
$$

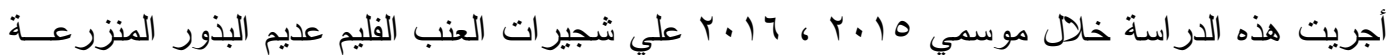

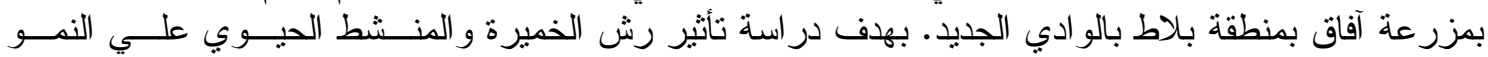

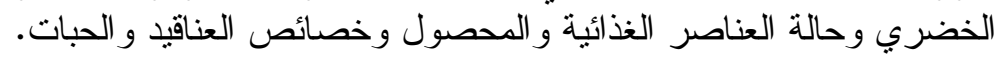

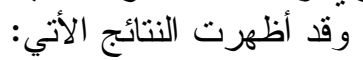

- أدي استخدام التسميد في الصورة الثنائية (معدني + حيوي) أو الصورة الثناثية (معسدني + خميــرة +

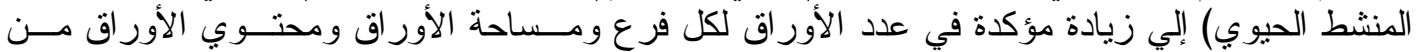

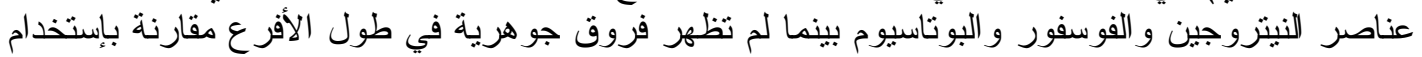
النسميد في الصورة المعدنية فقط. - سبب إستخدام التسميد في الصورة المركبة تحسين صفات العنقود و الثثار مقارنة بالتسميد المعـدني فقط. - أظهرت النتائج تفوق استخدام المنشط الحيوي مقارنة بإستخدام الخميرة.

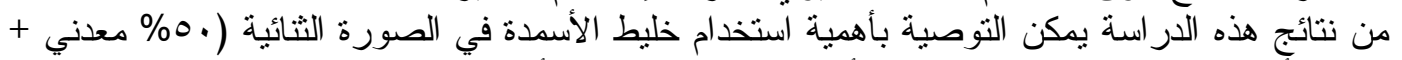

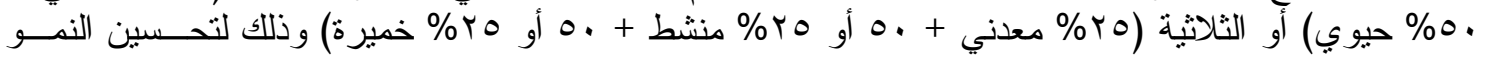

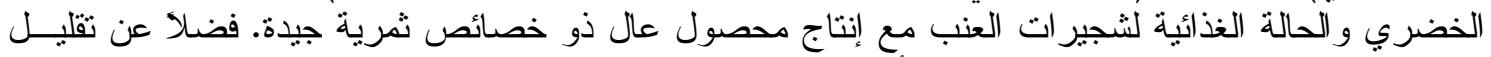
تكاليف التسميد والنلوث البيئي النانشئ عن الأسمدة المعدنية. 